Editorial

\title{
Special Issue: Materials for Nuclear Waste Immobilization
}

\author{
Neil C. Hyatt ${ }^{1}$ and Michael I. Ojovan ${ }^{1,2,3, *}$ \\ 1 Immobilisation Science Laboratory, Department of Materials Science and Engineering, \\ University of Sheffield, Mappin Street, Sheffield S1 3JD, UK; n.c.hyatt@sheffield.ac.uk \\ 2 Department of Radiochemistry, Lomonosov Moscow State University, Moscow 119991, Russia \\ 3 Imperial College London, South Kensington Campus, Exhibition Road, London SW7 2AZ, UK \\ * Correspondence: m.ojovan@sheffield.ac.uk
}

Received: 16 October 2019; Accepted: 1 November 2019; Published: 3 November 2019

\begin{abstract}
Nuclear energy is clean, reliable, and competitive with many useful applications, among which power generation is the most important as it can gradually replace fossil fuels and avoid massive pollution of environment. A by-product resulting from utilization of nuclear energy in both power generation and other applications, such as in medicine, industry, agriculture, and research, is nuclear waste. Safe and effective management of nuclear waste is crucial to ensure sustainable utilization of nuclear energy. Nuclear waste must be processed to make it safe for storage, transportation, and final disposal, which includes its conditioning, so it is immobilized and packaged before storage and disposal. Immobilization of waste radionuclides in durable wasteform materials provides the most important barrier to contribute to the overall performance of any storage and/or disposal system. Materials for nuclear waste immobilization are thus at the core of multibarrier systems of isolation of radioactive waste from environment aimed to ensure long term safety of storage and disposal. This Special Issue analyzes the materials currently used as well as novel materials for nuclear waste immobilization, including technological approaches utilized in nuclear waste conditioning pursuing to ensure efficiency and long-term safety of storage and disposal systems. It focuses on advanced cementitious materials, geopolymers, glasses, glass composite materials, and ceramics developed and used in nuclear waste immobilization, with the performance of such materials of utmost importance. The book outlines recent advances in nuclear wasteform materials including glasses, ceramics, cements, and spent nuclear fuel. It focuses on durability aspects and contains data on performance of nuclear wasteforms as well as expected behavior in a disposal environment.
\end{abstract}

Keywords: nuclear waste; spent nuclear fuel; immobilisation; conditioning; wasteforms; vitrification; glass; ceramics; glass composite materials; durability

Materials are at the core of multibarrier systems of isolation of radioactive (nuclear) waste from the environment. Relevant materials are used to ensure long-term safety of handling, storage, transportation, and disposal of nuclear waste. Nuclear waste immobilization is the conversion of waste into a wasteform by solidification, embedding, or encapsulation that reduces the potential for migration or dispersion of radionuclides during operational and disposal stages of waste lifecycle. Immobilization of waste is achieved by its chemical incorporation into the structure of a suitable matrix (typically cement, glass, or ceramic) so it is captured and unable to escape. Chemical immobilization is typically applied to high level waste (HLW). Encapsulation of waste is achieved by physically surrounding it in materials (typically bitumen or cement) so it is isolated, and radionuclides are retained. Physical encapsulation is often applied to intermediate level waste (ILW) but can also be used for HLW, especially where chemical incorporation of radionuclides in the surrounding matrix is also possible. 
Within the repository, the wasteform is one part of a multiple engineered barrier system. During storage and transportation, the wasteform is the primary barrier preventing the release of radionuclides into the environment, while during post closure disposal, the wasteform will reduce the release of radionuclides from breached and compromised containers that could result due to corrosion, earthquake, human intrusion, igneous intrusion (volcano), or other disruptive phenomena.

Choosing a suitable wasteform (matrix) to use for nuclear waste immobilization is not easy and its durability is not the sole acceptance criterion. Priority is given to reliable, simple, rugged technologies and equipment, which may have advantages over complex or sensitive equipment and processes. A variety of matrix materials and techniques are available for immobilisation [1-16]. The choice of the immobilization technology depends on the physical and chemical nature of the waste and the acceptance criteria for the storage and disposal facility to which the waste will be consigned.

Factors that are considered primarily when selecting a wasteform material are as follows [3,4]:

- Waste loading_able to accommodate a significant amount of waste (typically $25-45$ weight \%) to minimize volume;

- Ease of production-accomplished under reasonable conditions;

- Durability - low rate of dissolution to minimize the release of radioactive and chemical constituents;

- Radiation stability — high tolerance to radiation effects from the decay of radioactive constituents;

- Chemical flexibility-able to accommodate a mixture of radioactive and chemical constituents with minimum formation of secondary phases;

- Availability of natural analogues—availability of natural mineral or glass analogues may provide important clues about the long-term performance;

- Compatibility with the intended disposal environment-compatible with the near-field environment of the disposal facility.

A host of regulatory, process, and product requirements has led to the investigation and adoption of a variety of matrices and technologies for waste immobilization. The resistance of the wasteform to aqueous corrosion and release of radionuclides in the disposal environment—chemical durability—is a critical parameter. Figure 1 shows schematically the water durability of main nuclear wasteforms used.

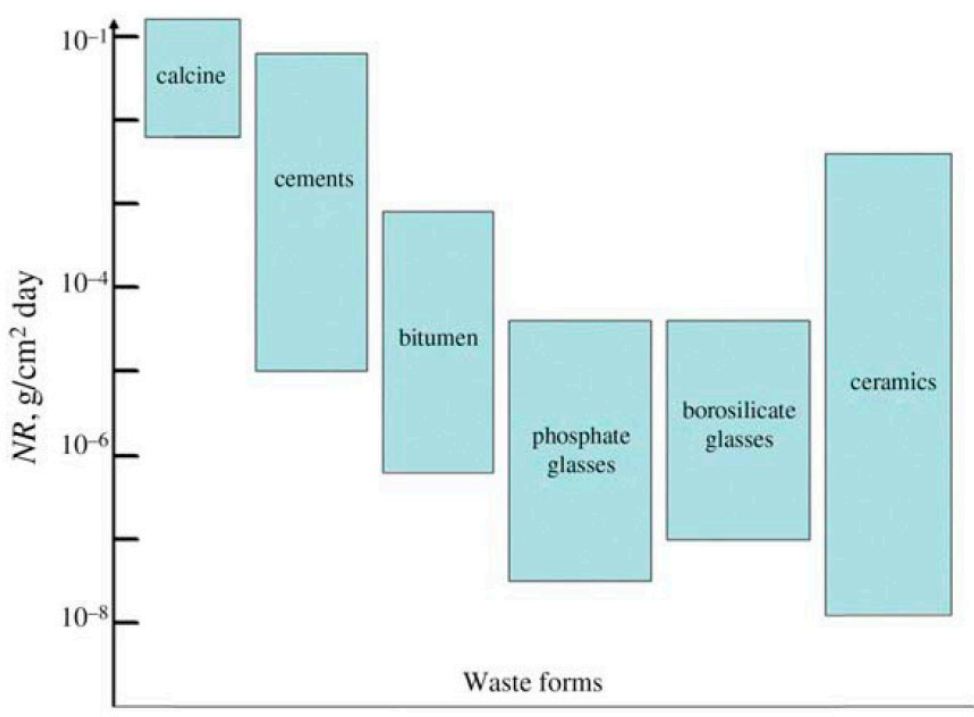

Figure 1. Normalized leaching rates of various wasteforms (after Reference [1]).

The main immobilization technologies that are available commercially and have been demonstrated to be viable are cementation [1-5] and vitrification [1,3,4,8-16], whereas bitumen and polymeric materaisl are used to a smaller extent (see data in [1]) and ceramification is a perspective 
technology $[1,3,6-8,12,14-16]$. Table 1 shows generic features and limitations of main wasteforms currently used on industrial scale.

Table 1. Features and limitations of main wasteforms currently used.

\begin{tabular}{|c|c|c|c|}
\hline Wasteform & Features & Limitations & Secondary Waste \\
\hline Glasses & $\begin{array}{l}\text { Proven method to condition liquid } \\
\text { high-level waste (HLW) as well as } \\
\text { intermediate-level waste (ILW) and } \\
\text { low-level waste (LLW). High flexibility in } \\
\text { terms of the glass formulation range. } \\
\text { High reliability of the immobilization } \\
\text { process. High glass throughput. High } \\
\text { durability of the final wasteform. Small } \\
\text { volume of the resulting wasteform. }\end{array}$ & $\begin{array}{l}\text { High initial investment and } \\
\text { operational costs. Complex } \\
\text { technology requiring high } \\
\text { qualified personnel. Need to } \\
\text { control off-gases. High specific } \\
\text { energy consumption. }\end{array}$ & $\begin{array}{l}\text { Off-gases. Filters. } \\
\text { Scrub solutions. } \\
\text { Used melters. }\end{array}$ \\
\hline Ceramics & $\begin{array}{l}\text { Possible to incorporate higher levels of } \\
\text { actinides than borosilicate glass. } \\
\text { Wasteform can be more durable than glass. } \\
\text { Expected to be suitable for long term } \\
\text { isolation since it simulates natural rocks. }\end{array}$ & $\begin{array}{l}\text { Limited experience. Most efforts } \\
\text { have been research-based. } \\
\text { The ceramic shall be tailored to } \\
\text { nuclear waste composition. }\end{array}$ & $\begin{array}{l}\text { Filters. Off-gases. } \\
\text { Scrub solutions. }\end{array}$ \\
\hline Cements & $\begin{array}{l}\text { Widely used method for variety of LLW } \\
\text { and ILW. High flexibility. Low cost. } \\
\text { Simplicity of process. Low temperature } \\
\text { precludes volatile emissions. High } \\
\text { radiation stability, impact, and fire } \\
\text { resistance of wasteforms. }\end{array}$ & $\begin{array}{l}\text { Increase of volume (low waste } \\
\text { loading). Low retention of some } \\
\text { fission and activation products. } \\
\text { Poor compatibility with organic } \\
\text { materials and high-salt content. }\end{array}$ & None. \\
\hline Bitumen & $\begin{array}{l}\text { Mostly used for LILW, chemical } \\
\text { precipitates, low heat, and low alpha } \\
\text { wastes. High flexibility. High } \\
\text { compatibility with organic materials. } \\
\text { High waste loading. Lower leaching rate } \\
\text { compared with cements. }\end{array}$ & $\begin{array}{l}\text { Sensitivity to some components. } \\
\text { Low fire resistance. }\end{array}$ & Filters. \\
\hline
\end{tabular}

The general requirements against one another need optimization for any technological approach considered. For example, ceramics are credited with having higher chemical durability than glasses, however, radionuclides will be released at similar or even higher rates compared with glassy wasteforms (see, e.g., Figure 1) if they are incorporated in the lower durability crystalline phases and intergranular glassy phases.

This book contains 10 dedicated papers prepared by lead researchers covering different aspects of nuclear wasteforms and their expected behavior. They purposely analyze the materials currently used as well as novel materials for nuclear waste immobilization including technological approaches utilized in nuclear waste conditioning pursuing to ensure efficiency and long-term safety of storage and disposal systems, including cementitious materials, glasses, and ceramics. The book outlines recent advances in nuclear wasteform materials including cements, glasses, ceramics, cements, and spent nuclear fuel with focus on durability aspects and presenting data on performance of nuclear wasteforms, as well as expected behavior in a disposal environment.

Funding: This research received no external funding.

Conflicts of Interest: The authors declare no conflict of interest. 


\section{References}

1. Ojovan, M.I.; Lee, W.E.; Kalmykov, S.N. An Introduction to Nuclear Waste Immobilisation, 3rd ed.; Elsevier: Amsterdam, The Netherlands, 2019; p. 497.

2. Abdel Rahman, R.O.; Rahimov, R.Z.; Rahimova, N.R.; Ojovan, M.I. Cementitious Materials for Nuclear Waste Immobilization; Wiley: Chichester, UK, 2015; p. 232.

3. Lee, W.E.; Ojovan, M.I.; Jantzen, C.M. Radioactive Waste Management and Contaminated Site Clean-up: Processes, Technologies and International Experience; Woodhead: Cambridge, UK, 2013; p. 924.

4. National Research Council. Waste Forms Technology and Performance: Final Report; National Academies Press: Washington, DC, USA, 2011; p. 308.

5. Glasser, F. Application of inorganic cements to the conditioning and immobilisation of radioactive wastes. In Handbook of Advanced Radioactive Waste Conditioning Technologies; Ojovan, M.I., Ed.; Woodhead: Cambridge, UK, 2011; pp. 67-135, 512.

6. Kinoshita, H. Development of ceramic matrices for high level radioactive waste. In Handbook of Advanced Radioactive Waste Conditioning Technologies; Ojovan, M.I., Ed.; Woodhead: Cambridge, UK, 2011; pp. $67-135,512$.

7. Burakov, B.E.; Ojovan, M.I.; Lee, W.E. Crystalline Materials for Actinide Immobilisation; Imperial College Press: London, UK, 2010; p. 198.

8. Donald, I.W. Waste Immobilisation in Glass and Ceramic Based Hosts; Wiley: Chichester, UK, 2010; p. 507.

9. Jantzen, C.M.; Brown, K.G.; Pickett, J.B. Durable glass for thousands of years. Int. J. Appl. Glass Sci. 2010, 1, 38-62. [CrossRef]

10. Caurant, D.; Loiseau, P.; Majerus, O.; Aubin-Chevalsdonnet, V.; Bardez, I. Quintas, A. Glasses, Glass-Ceramics and Ceramics for Immobilization of Highly Radioactive Nuclear Wastes; Nova Science Publishers: New York, NY, USA, 2009; p. 359.

11. Ojovan, M.I.; Lee, W.E. New Developments in Glassy Nuclear Wasteforms; Nova Science Publishers: New York, NY, USA, 2007; p. 131.

12. Lee, W.E.; Ojovan, M.I.; Stennett, M.C.; Hyatt, N.C. Immobilisation of radioactive waste in glasses, glass composite materials and ceramics. Adv. Appl. Ceram. 2006, 105, 3-12. [CrossRef]

13. Vienna, J.D. Nuclear Waste Glasses. In Properties of Glass Forming Melts; Pye, L.D., Joseph, I., Montenaro, A., Eds.; CRC Press: Boca Raton, FL, USA, 2015; pp. 391-404, 512.

14. Stefanovsky, S.V.; Yudintsev, S.V.; Giere, R.; Lumpkin, G.R. Nuclear waste forms. In Energy, Waste and the Environment: A Geochemical Perspective; Gieré, R., Stille, P., Eds.; Geological Society of London: London, UK, 2004; pp. 37-63, 688.

15. Ewing, R.C. The Design and Evaluation of Nuclear-waste Forms Clues from Mineralogy. Canadian Mineralogist 2001, 39, 697-715. [CrossRef]

16. Lutze, W.; Ewing, R.C. Radioactive Waste Forms for the Future; Elsevier: Amsterdam, The Netherlands, 1988; p. 778.

(C) 2019 by the authors. Licensee MDPI, Basel, Switzerland. This article is an open access article distributed under the terms and conditions of the Creative Commons Attribution (CC BY) license (http://creativecommons.org/licenses/by/4.0/). 